\title{
BIOTA/FAPESP, Brazil's Model Program for Assessing Global Biodiversity
}

\author{
James T. Staley \\ Received:September 05, 20001 \\ Accepted:September 05, 2001 \\ Department of Microbiology \\ University of Washington \\ Seattle, WA 98195
}

\begin{abstract}
Brazils state of São Paulo ranks among the few governments that has recognized the importance of biodiversity. It has successfully launched Biota as part of its FAPESP program in biology. The Biota program has been in operation for three years now, long enough to pose questions about its promise. The questions I will try to address here are:

What attributes of the Biota progam have allowed it to succeed where others have failed?

Can the Biota program serve as a global model for biodiversity efforts?
\end{abstract}

\section{Resumo}

O governo do Estado de São Paulo, Brasil, está entre os poucos no mundo que reconheceram a importância da biodiversidade, implantando com sucesso o Biota/FAPESP como parte de seu programa de pesquisas na área de Ciências Biológicas. Agora que já fazem três anos que o Programa BIOTA/FAPESP está e funcionamento é o momento certo para nos colocarmos algumas questões sobre o seu sucesso. As questões que eu vou tratar neste artigo são:

Quais as características que garantiram o sucesso do BIOTA/FAPESP numa área onde, ao redor do mundo, outras iniciativas falharam?

Podemos utilizar o BIOTA/FAPESP como modelo para Programas de Pesquisa em Conservação e Uso Sustentável da Biodiversidade no mundo?

Key Words: Biodiversity; BIOTA/FAPESP; Assessing Global Biodiversity; Scientific Advisory Committee; State of São Paulo; Brazil.

Palavras-chave: Biodiversidade; BIOTA/FAPESP; Avaliando a biodiversidade global; Scientific Advisory Committee; Estado de São Paulo; Brasil. 


\section{Introduction}

Earths creatures are not only unique but they are the most valuable matter in the Universe. They are of far greater consequence than the worlds mineral and energy resources. Yet, many governments and citizens have mixed feelings about the importance of organisms.

The ambivalent attitude of humans toward other species likely stems from our changing perception of our place on Earth. On the one hand, humans have great respect and affection for plant and animal life. Ancient civilizations worshiped animals or mythical creatures because of their strength, their ability to fly or their uncanny senses of sight, hearing and smell.

Yet, at the same time, a common attitude of humans is that Nature must be conquered and held under human control. This view likely springs from the competitive struggle that our species, which evolved about 100,000 years ago, developed while taking reign over a wild and sometimes dangerous planet. Indeed, it has been only in the past few thousand years that humans have had any great impact on the planet's biological resources at all. Animals and plants have always been important as resources to be exploited for food, shelter and clothing, and still are. And wild animals, especially large carnivores, were a threat to the existence of humans and were duly eradicated, and still are.

\section{The Human Impact on Biodiversity}

During the past few thousand years, Earth has been undergoing a dramatic transformation. As humans left Africa and colonized other continents, many animal and plant species were driven to extinction by over-hunting and over-harvesting (Diamond, 1997). Such was the fate of the North American mammoth, the large Australian marsupials and the New Zealand moa. A single example, that of the Rapanui people of Easter Island, illustrates this lesson well. When the Dutch ship Afrikaansche Galei visited Easter Island in 1722, Captain Jakob Roggeveen noted that there was not a single tree. However, more recently anthropologists have discovered pollen from extinct trees that was preserved in soil profiles. From this they concluded that the island was at one time forested like other Pacific Islands. Apparently, the Rapanui harvested all of their trees for shelter, clothing and food until the trees were driven to extinction (Flannery, 1994). The result is that an island that previously supported about 8,000 inhabitants and developed its own written language and distinctive culture, could now support only an impoverished population of hundreds. Furthermore, the Rapanui lacked clothing and lived in caves.

Now it is abundantly clear that the human species, which has harnessed animals and farmed plants, has succeeded in its "conquest" of Nature. The result is a human population that has exploded and multiplied into the billions. Correspondingly, this continuing increase in population has had a startling impact on our fellow inhabitants of this planet. Biologists are alarmed about the loss of species diversity by a variety of human activities such as agriculture, fisheries, mining and industry all of which pose hazards to environments and threaten native species. Furthermore human activities have resulted in the transplantation of species from one place on Earth to another. Many of these transplanted plants and animals have become invasive species in the new habitat where they flourish and threaten native species and ecosystems.

The impact of human activities is the major force driving the most recent mass extinction of life on Earth. In the next few decades, increasing numbers of plant and animal species are projected to become extinct. Faced with this daunting predicament, one would expect that governments and scientists would be planning massive research and conservation programs aimed at stemming the loss of this invaluable and irreplaceable resource. But, this is not happening. We must ask ourselves why? Why will governments spend millions or billions of dollars on their economies and completely neglect their most valuable resource--biodiversity? Is it simply because it has no apparent economic value other than that obtained in harvesting? How can some governments spend more on the exploration of space, which has no clear economic virtue, than on the study of the unexplored and vast diversity of life here on Earth the only planet known that contains life?

\section{A Biodiversity Maxim}

Humans are carrying out a gigantic experiment in which the state of life on the planet is teetering and most governments continue to go about their everyday activities seemingly oblivious to the matter. How surprising this all is considering that the biblical story of Noah, who saved the animals during the great flood, indicates that humans regard all life as precious and sacred. As ambivalent as humans may be about the value of other living organisms, the human species recognizes that it has a moral responsibility as the caretaker of Earth's biodiversity. Among the consequences of ignoring our moral duty to biodiversity will be, if not the extinction of our own species, the continuing and irreversible loss of fellow creatures with whom we have evolved and who provide us with such joy. Our neglect will bring upon us the rightful wrath of future generations.

Biologists are the professional custodians of this vast and marvelous diversity. Why have biologists failed to convey to the world that Earths organisms are the canaries of the biosphere and as such, their loss may portend even our own extinction? What can and should we do to educate the public and begin to take action? I suggest that biologists need to work together in a more effective way. We must convince our brothers and sisters in our own countries and throughout the world of the moral value of the Biodiversity Maxim: All species are unique and precious. Of course, the best way to convince people of the importance of biodiversity is to develop an organized program of research and education. That is why the Biota program is so 
important. The Biota program provides the first operating framework for a successful governmental program in biodiversity.

\section{The BIOTA/FAPESP Program}

Brazils state of São Paulo ranks among the few governments that has recognized the importance of biodiversity. It has successfully launched Biota as part of its FAPESP program in biology. The BIOTA/FAPESP Program has been in operation for three years now, long enough to pose questions about its promise. The questions I will try to address here are:

- What attributes of the BIOTA/FAPESP Progam have allowed it to succeed where others have failed?

- $\quad$ Can the BIOTA/FAPESP Program serve as a global model for biodiversity efforts?

However, it is important to first provide some perspective of my own experience with the Biota program. I was a member of the first, three-member site visit team, or Scientific Advisory Committee, that met with BIOTA/FAPESP administrators and scientists at the State University of Campinas, São Paulo in 1999. Then in 2000, I was part of a four-member site visit advisory board that attended the annual BIOTA/FAPESP meeting in Parque Estadual Intervales. So, I have had a special opportunity to learn first-hand about many of the activities that are underway in the progam. Although, as a microbiologist, I am not familiar with the details of all of the work that is underway in the various disciplines in biology, I believe I have a good understanding of the major attributes of the people and program that have allowed it to become so successful.

The first attribute of the program that I believe is critical to its operation are its people, in particular, the scientists and students as well as the staff and technical help that are responsible for collecting and analyzing field and laboratory information. They are the heart of the program, for without them the science would not occur. What is particularly noteworthy about this group of scientists is that it truly encompasses scientists in all aspects of organismal biology from microbes to primates.

But a biodiversity effort requires more than the individual science labs, however distinguished they may be, it requires that they work together in an interdisciplinary setting. For example, it is not enough to know and understand the species distributions of zooplankton in a lake if one is interested in biodiversity. It is essential to understand also, the invertebrates and fish that live on the zooplankton,

the phytoplankton the feed to zooplankton and the bacteria that are involved in the turnover of nutrients that affect the growth of all organisms. Furthermore, it is essential to understand the physical and chemical factors that influence the biology of the lake. And finally the lake exists in a watershed with the plants, animals and microorganisms as well as physical and chemical features which also have an impact on the lake. So, the successful biodiversity effort involves team work and interraction among various disciplines. Open and good communication is the key to making this a success.

The second attribute is appropriate size. The success of a biodiversity program depends on the interest and support of a receptive and informed citizenry. This occurs at the local level, in watersheds, in agricultural belts or transitional zones between land and sea. It is the people who live in a particular area who are most interested in the biota of the area because they are so well acquainted with the species - after all, they are fellow occupants of their everyday lives. So, it seems much more reasonable that the citizens of a locality will have the interest and familiarity with the biota and will be supportive of its study. On the other hand, in order that there are a sufficient number of expert scientists, the area needs to have universities, museums and research centers with the needed expertise to study the biota. The State of São Paulo is an appropriate size, not too big and not too small in which to undertake a meaningful biodiversity effort.

Of course, none of this could have happened were it not for leadership. Key leaders in science and government play perhaps the most critical role in seeing that a program in biodiversity happens. The leaders must convince the politicians and populace of the importance of biodiversity while at the same time produce a balanced and effective scientific program.

Finally, the local habitats and diverse biota of Brazil make it a natural location for launching biodiversity efforts. There are many species to be studied and much to be learned about how they interact with one another, their environments and the local citizens. The goals of a program in biodiversity must be directed toward understanding how the biota can be sustained in the face of human populations that increasingly encroach upon their habitats and life styles.

\section{Beyond São Paulo State}

BIOTA/FAPESP is in a unique position to serve as a model for biodiversity efforts not only in Brazil and Latin America but for the rest of the world. Brazils BIOTA/FAPESP leaders and scientists can teach others about how to go about creating a successful program in biodiversity. It would seem that small countries are of the appropriate size to launch other efforts and could greatly benefit from Brazils model.

A reasonable initial goal would be to extend the program to other states in Brazil. Indeed, there are logical extensions of the program into other states already.

Of course, the world needs leadership in biodiversity. A successful program such as BIOTA/FAPESP is the envy of biologists in other countries. BIOTA/FAPESP scientists 
can take a leadership role in promulgating the organization of biodiversity efforts throughout the world.

\section{References}

Diamond, J. 1997. Guns, germs and steel. W.W. Norton \& Co. New York.

Flannery, T. F. 1994. The future eaters. Reed New Holland, Sydney.

Title: BIOTA/FAPESP, Brazil's Model Program for Assessing Global Biodiversity

Author: James T. Staley

Biota Neotropica, Vol. 1, numbers 1 and 2, 2001 - Bn00501122001

ISSN 1676-0611

Date received september / 04 / 2001 